\title{
PEDAGOGIKA PORÓWNAWCZA W SYSTEMIE WSPÓŁCZESNEJ WIEDZY NAUKOWEJ
}

Streszczenie: Metodologia badań porównawczo-pedagogicznych przechodzi obecnie pewne zmiany, których zakres stanowi przedmiot zainteresowań badaczy z innych dziedzin. Punktem wyjścia niniejszego artykułu są teoretyczne i metodologiczne podstawy pedagogiki porównawczej. Pierwsza część opracowania wprowadza w problematykę teoretycznych i metodologicznych podstaw pedagogiki porównawczej. Autor przedstawia cele i definicje pedagogiki porównawczej, a także opisuje znaczenie, jakie ma ona dla rozwoju systemu oświatowego. Druga część poświęcona jest historycznemu spojrzeniu na rozwój pedagogiki porównawczej. W kolejnej części artykułu przedstawione zostały etapy rozwoju pedagogiki porównawczej. Ostatni podrozdział dotyczy procesów globalizacji w przestrzeni edukacyjnej.

Słowa kluczowe: pedagogika porównawcza, badanie porównawcze, komparatystyka, metodologia, metoda sieci.

\section{Wprowadzenie}

Komparastyka jako w naukach pedagogicznych, istotnie podkreślona przez Pierre’a Bourdieu, Michela Espagne’a i Marcela Detienna ma duże znaczenie. Chęć prowadzenia badań porównawczych nie zniknęła wśród naukowców. Wręcz przeciwnie, $w$ różnych dyscyplinach zaobserwowano zwiększenie liczby przeprowadzanych badań, choć marzenia historyków Marca Blocha i Fernanda Braudela o konieczności wykorzystywania w badaniach porównawczych osiągnięć nauk społecznych są jeszcze dalekie od spełnienia. Wielu badaczy z różnych środowisk

\footnotetext{
* Dr hab. Olena Bocharova, prof. uczelni, Uniwersytet Pedagogiczny im. KEN w Krakowie; e-mail: olena.bocharova@up.krakow.pl.
} 
angażuje się stale $\mathrm{w}$ prowadzenie badań porównawczych (Nóvoa, Yariv-Mashal 2003b, s. 57).

Od połowy XX wieku toczą się dyskusje dotyczące przedmiotu, celów i metod badawczych w obrębie pedagogiki porównawczej. Ponadto problem stanowi różnorodna, niejednolita terminologia $\mathrm{w}$ tym zakresie. $\mathrm{W}$ trakcie przeprowadzenia badań badacze napotykają na trudności językowe, wynikające z wielości znaczeń i pojęć. Do dnia dzisiejszego nie udało się sformułować nawet uniwersalnej nazwy komparystyki pedagogicznej. W krajach o anglosaskich tradycjach naukowych (USA, Wielka Brytania, Australia) zadomowił się termin „edukacja porównawcza” (comparative education), natomiast badacze europejscy (Polska, Ukraina) używają terminu „pedagogika porównawcza” (comparative pedagogy). W Niemczech z kolei używa się w tym zakresie dwóch pojęć: „edukacja porównawcza” (Vergleichende Erziehungswissenschaft) i „pedagogika porównawcza” (Vergleichende Pädagogik).

We Francji przez długi czas dominował termin "pedagogika porównawcza” (pédagogie comparée), jednak w latach 80. XX wieku został on zastąpiony terminem „edukacja porównawcza” (éducation comparée) (Lé Thànk Kôi 1981, s. 43).

Wśród rosyjskich badaczy nie ma zgody w używaniu terminu „pedagogika porównawcza”. Niektórzy uważają, że nie warto naśladować państw zachodnich, natomiast inni preferują termin „edukacja porównawcza”, jeszcze inni zaś - „komparatystyki pedagogicznej" (Dudko 2018, s. 62). Francuski komparatysta Hank Van Daele tłumaczy to tym, że termin „pedagogika”, rozpowszechniony w wiekach XVIII i XIX oznaczał naukę o wychowaniu i kształceniu dzieci. Dopiero wiek XX zmienił spojrzenie na edukację, ponieważ kształcenie człowieka trwa przez całe życie. Właśnie pod tym względem pojęcie „pedagogiki porównawczej” ustąpiło miejsce terminowi „edukacji porównawczej” (Van Daele 1993, s. 18).

Dwa wieku temu Marc-Antoine Jullien de Paris, intelektualista, pedagog i przyjaciel Johanna Heinricha Pestalozziego, i Alexandra von Humboldta dostrzegł istotną rolę edukacji dla rozwoju i dobrobytu społeczeństw europejskich. Był przekonany, że jeśli narody mniej rozwiniętych krajów mogą doświadczyć skutecznych praktyk edukacyjnych $\mathrm{w}$ innych krajach, to mogłyby skorzystać $\mathrm{z}$ ich postępów (Mattheou 2006, s. 6).

Hank Van Daele (1993, s. 16-17) traktował pedagogikę porównawczą ,jako wielowymiarowy element nauk o edukacji, którego celem jest zbadanie zjawisk edukacyjnych w kontekście społecznym, politycznym, ekonomicznym i kulturowym; porównywanie podobieństw i różnic w dwóch lub więcej regionach, krajach, kontynentach, $w$ tym na poziomie światowym w celu lepszego zrozumienia pożądanych cech dla poprawy własnego systemu edukacji”.

Natomiast w Słowniku edukacji porównawczej (Dictionnaire d'éducation comparée) pod red. Dominique Groux i Soledada Perez (2002, s. 19) można przeczytać, iż „pedagogika porównawcza bada zjawiska pedagogiczne nie tylko w celu heurystycznym, lecz także w celu poprawy sytuacji edukacyjnej poprzez czerpanie inspiracji z tego, co już zrobiono gdzie indziej. Pedagogika porównawcza 
bada systemy edukacyjne; podkreśla podobieństwa i różnice oraz wyjaśnia je w kontekście politycznym, historycznym, ekonomicznym i społecznym; bierze pod uwagę to, co może być przeniesione do innego kontekstu $\mathrm{z}$ uwzględnieniem czynników lokalnych”. Z kolei Robert Thomas (1990, s. 25) uważa, że „pedagogika porównawcza zajmuje się badaniem dwóch lub więcej systemów edukacyjnych w celu uzyskania informacji: co mają one wspólnego i czym się różnią". Poznanie doświadczeń innych państw w różnych dziedzinach jest motorem rozwoju nauki. W naukach ścisłych i przyrodniczych wyniki badań porównawczych nie wymagają szczegółowej analizy z uwzględnieniem systemu wartości, czynników społeczno-kulturowych i ekonomicznych. Natomiast w naukach społecznych tym aspektom poświęca się szczególną uwagę.

Zdaniem Dominique Groux komparystyka pedagogiczna ma na celu poznanie międzynarodowych i narodowych realiów edukacyjnych w ich globalnym kontekście, zarówno w celu poznawczym, jak i poprawy obecnej sytuacji w edukacji (Groux 1997, s. 112). W opinii Gilberta de Landsheere’a istotą „pedagogiki porównawczej jest analiza i interpretacja praktyki i polityki systemów edukacji różnych państw i różnych kultur (De Landsheere 1972, s. 90). Le Thành Khôi (1981, s. 90) uważa zaś, że „pedagogika porównawcza pomaga lepiej zrozumieć to, czego doświadczamy, do czego się odwołujemy. Problemy rozpatrywane z różnych perspektyw pozwalają badaczowi skupić się na zbadaniu zjawiska, cofnąć się lub zmienić swój punkt widzenia. Pedagogika porównawcza akcentuje uwagę na różnicach oraz rozważa każdy system edukacyjny jako całość”. Celem badań komparatystyczno-pedagogicznych jest określenie paradygmatów edukacyjnych ogólnych i narodowych; badanie pozytywnych i negatywnych doświadczeń międzynarodowych w edukacji; określenie granic „przenoszenia” doświadczeń zagranicznych na grunt krajowy. W opinii francuskiego komparatysty Luisa Porchera (2008, s. 281) celem pedagogiki porównawczej jest badanie i prezentowanie doświadczeń zagranicznych; przekształcanie i ulepszanie własnego systemu edukacyjnego na podstawie uzyskanych danych z innych państw.

Nie można nie zgodzić się ze zdaniem Dominique Groux (1997, s. 115), iż „porównywanie $\mathrm{w}$ edukacji zawsze ma sens. Jeśli porównanie jest przeprowadzone w sposób rygorystyczny, z uwzględnieniem cech wspólnych i różnic ogólnego zjawiska, to dostarcza ono więcej informacji niż badanie tego samego zjawiska w pojedynczym kontekście. Na przykład przemoc nie przejawia się w ten sam sposób w każdej szkole, jednak formy przemocy są podobne (gwałty, przemoc słowna i fizyczna). Natomiast zasoby powstrzymania agresji mogą mieć charakter globalny”. Oznacza to, że porównywanie w edukacji jest ekonomicznie wygodne, ponieważ pozwala uniknąć badań, które już zostały przeprowadzone $\mathrm{w}$ innych państwach i można z nich skorzystać. Jesteśmy obecnie świadkami globalizacji odnoszącej się do obszarów ludzkiej działalności i dlatego też wydaje się konieczne odwołanie się do międzynarodowych badań porównawczych. 
Celem niniejszego artykułu jest poznanie teoretycznych i metodologicznych podstaw pedagogiki porównawczej.

\section{Historia i rozwój pedagogiki porównawczej}

W XIX wieku „ojciec” pedagogiki porównawczej Marc Antoine Jullien de Paris w swojej pracy Szkice i przygotowania przedwstępne do pracy o edukacji porównawczej (Esquisse et vues préliminaires d'un ouvrage sur l'éducation comparée, 1817) jako pierwszy sformułował cel, przedmiot, funkcje i metody porównawczych badań pedagogicznych. Przez komparatyzm pedagogiczny rozumiał porównywanie treści i metod kształcenia w instytucjach edukacyjnych w różnych krajach. Jego zdaniem, gromadząc, segregując i porównując fakty, można odkryć pewne reguły i prawidłowości. Porównanie ma na celu wykorzystanie najlepszych wzorców i wprowadzenie ich do własnego systemu edukacyjnego. Uważał komparatystykę pedagogiczną za jeden z najważniejszych zasobów opracowania teorii pedagogicznej wspólnej dla wszystkich krajów europejskich, która w przyszłości sprzyjałaby postępowi kulturowemu i spójności między narodami. Aby komparatyzm pedagogiczny był nauką użyteczną, powinien opierać się na materiale faktograficznym $\mathrm{z}$ różnych krajów (Jullien de Paris 1817, s. 8-9).

Później jego metoda zbierania, porównania i wdrażania danych w praktykę edukacyjną została skrytykowana przez Michaela Sandlera. Pierwszy dyrektor departamentu badań w Board of Education, prekursor Ministerstwa Edukacji w Londynie, opracował teorię charakteru narodowego jako siły dominującej w wychowaniu, formułując myśl, że każdy krajowy system edukacji składa się z kilku elementów i musi być badany w odniesieniu do kontekstu społecznego. Szkoły są integralną częścią społeczeństwa, w którym działają. M. Sandler i jego zwolennicy, w tym George Bereday, Friedrich Schneider i Isaac Kandel, byli zdania, że o rozwoju systemu edukacji decydują czynniki społeczno-ekonomiczne. Według M. Sandlera, ,„dla zrozumienia systemu edukacji, to co się dzieje poza szkołą, ma większe znaczenie niż to, co ma miejsce w szkole. Korzyść praktyczna z porównywania zagranicznych systemów edukacyjnych polega na tym, że zaczynamy lepiej rozumieć własny system" (Sandler 1900, 1964, s. 311). W książce Jak dużo możemy się nauczyć czegoś praktycznego z badań nad zagranicznymi systemami edukacyjnymi? (How far can we Learn Anything of Practical Value from the Study of Foreign Systems of Education?, 1900) M. Sandler zakładał, iż edukacja jest mocno związana ze strukturą społeczeństwa (ustrój państwa, gospodarka, rodzina, kościół), a czynniki oddziaływające na rozwój społeczeństwa determinują kierunek rozwoju edukacji. W związku z tymi dwoma kluczowymi założeniami badacz ten uważał, że analizę porównawczą zjawisk edukacyjnych warto przeprowadzać na tle czynników społecznych (Sandler 1900, s. 312).

Natomiast Nicholas Hans wyraził przekonanie o ważności teorii funkcjonalizmu w badaniach porównawczych. Jego zdaniem społeczeństwo jest systemem 
składającym się z wzajemnie powiązanych ze sobą czynników i właśnie dlatego zamiast analizy statystycznej należy stosować analizę funkcjonalną - porównanie instytucji edukacyjnych z punktu widzenia ich rozwoju historycznego (Hans 1948, s. 23).

Szczyt badań w pedagogice porównawczej przypada na lata 30-50. XX wieku. W tym okresie badacze byli przekonani, że edukacja nie jest oderwana od społeczeństwa i także podlega wpływom społecznym. Poszukując „nieuchwytnych sił duchowych i kulturowych, które kształtują system światowy”, badacze sformułowali cel pedagogiki porównawczej, rozumianej jako „szczegółowy opis narodowych systemów edukacji w kontekście społecznym, politycznym, ekonomicznym i kulturowym" (Lokszyna 2014, s. 6).

Isaak Kandel w pracy Pedagogika porównawcza (Comparative Education, 1933) zaproponował w badaniach porównawczych uwzględnienie uwarunkowań narodowo-państwowych, społeczno-ekonomicznych i kulturowych. Zatem jego podejście do metodologii badań porównawczych opierało się nie na zwykłym opisaniu systemów edukacyjnych i strategii ilościowej, lecz na zastosowaniu strategii jakościowej oraz analizie wyodrębnionych przez niego czynników. Ponadto, analizując problemy edukacji, ważne jest ustalenie ich przyczyn, dlatego też zdaniem tego autora winno skupić się na różnicach występujących w poszczególnych krajach. Nadto I. Kandel uznawał krajowe systemy edukacji za laboratoria, w których można testować różne rozwiązania problemów systemów narodowych na tle innych państw. Od momentu, gdy narodziła się pedagogika porównawcza, miał on nadzieję, że „wniesie ona istotny wkład w rozwój filozofii edukacji i światowej teorii edukacji i w rezultacie współpracy w dziedzinie edukacji państwom uda się osiągnąć porozumienie w wielu obszarach" (Kandel 1957, s. 3-18).

Koniec lat 6o. XX wieku charakteryzuje się sporą liczbą badań porównawczych. Właśnie w tym okresie na całym świecie pojawiło się wiele prac $\mathrm{z}$ pedagogiki porównawczej. Ich autorami byli m.in. Brian Holmes (Problemy w edukacji: Podejście porównawcze, 1965, tytuł oryg. Problems in Education: A Comparative Approach), Harold J. Noah i Max A. Eckstein, którzy wydali opracowanie pt. W kierunku nauki o edukacji porównawczej (Toward a Science of Comparative Education, 1969)), Aleksander Vexliard (Pedagogika porównawcza. Metody i problemy, 1967, tytuł oryg. La pédagogie comparée. Methods and Problems), Juan Tusquets (Teoria i praktyka pedagogiki porównawczej, 1969, tytuł oryg. Teoría y prácfica de la Pedagogía Comparada).

Poza tym zainteresowanie problemami pedagogiki porównawczej doprowadziło do powstania wielu czasopism wydawanych przez stowarzyszenia zajmujące się edukacją porównawczą: w Wielkiej Brytanii - Comparative Education Review (1965); Kanadzie - Convergence (1968) i Éducation canadienne et internationale Canadian and International Education (1972); we Francji - Éducation comparée (1973). Od 1956 roku Amerykańskie Stowarzyszenie Edukacji Porównawczej 
wydawało czasopismo Comparative Education Review. Okres ten można uznać za „nową erę rozwoju badań porównawczych” (Halls 1990, s. 45).

Kolejne pokolenie komparatystów takich jak Harold Noah i Max Eckstein zwróciło uwagę na fakt, że zarówno w kontekście szybkiego rozwoju gospodarczego, jak i odkryć w dziedzinie nauk ścisłych oraz procesów demokratycznych zachodzących w Europie i Ameryce podejście historyczne w badaniach pedagogiczno-porównawczych było niewystarczające, były one bowiem „zbyt małe w swojej perspektywie i zbyt ambitne w swoich celach; nie odpowiadało potrzebom społeczeństw; było „nienaukowe, tym samym nie mogło ustalić związków przyczynowo-skutkowych oraz przyczynić się do ulepszenia własnego systemu edukacji” (Noah, Eckstein 1969, s. 44). Według wspomnianych autorów, pedagogika porównawcza powinna pomóc w wyjaśnieniu obserwowanych zjawisk w edukacji i społeczeństwie. Badacze uważali metodę prognostyczną za najbardziej efektywną i proponowali przeprowadzenie badania opartych nie na intuicji komparatystów, lecz na teorii naukowej.

Interdyscyplinarny charakter badań porównawczych, jako swoisty rodzaj pomostu między badaniami historyków i humanistów, był głoszony przez George’a Bereday’a. W jego opinii w badaniu porównawczym koniecznie jest rozumienie i wyjaśnienie konkretnych zjawisk edukacyjnych. Według tego badacza analiza miała na celu zidentyfikowanie wspólnych czynników. Był zwolennikiem metody indukcyjnej. G. Bereday uważał, że przy prowadzeniu badań porównawczych badacz powinien przestrzegać następujących zasad: 1) opisać system edukacji badanego kraju; 2) przeanalizować oddziaływanie czynników społeczno-gospodarczych na rozwój systemów edukacji; 3) porównać dane badanego kraju w celu ustalenia cech wspólnych i odmiennych z własnym; 4) wskazać cechy niezbędne dla ulepszenia własnego systemu edukacji (Bereday 1964, s. 82). Zwolennikiem interdyscyplinarnego podejścia był także Brian Holmes. W swojej pracy Problemy w edukacji. Podejście porównawcze (Problems in Education: A Comparative Approach, 1965) pisał, że „przyszłość pedagogiki porównawczej zależy od korzystania z wiedzy i danych z innych dyscyplin naukowych"(Holmes 1965, s. 76).

$\mathrm{W}$ latach 80 . XX wieku rozwój porównawczych badań pedagogicznych prowadzony był w kontekście filozoficznego rozumienia świata. Przedmiotem badań komparatystów stały się badania w skali międzynarodowej. Był to nowy okres rozwoju; pedagogika porównawcza była odkrywana na nowo w wyniku zjawisk globalizacji, tak jak to miało miejsce pod koniec lat 6o. XX wieku w wyniku zastosowania danych ilościowych przez organizacje międzynarodowe.

Lata 90. XX wieku - to nowy etap rozwoju społeczeństw europejskich. Charakteryzuje się on zjawiskiem internacjonalizacji i globalizacji. Przedmiotem badań komparatystów staje się teoria kapitału ludzkiego. Różnorodne poglądy na temat istoty kapitału ludzkiego wskazują na główne grupy działań rozwijających ludzkie umiejętności, takie jak: formalne kształcenie szkolne na wszystkich poziomach nauczania; szkolenia w czasie pracy, programy studiów dla dorosłych, usługi związane z ochroną zdrowia wpływające na witalność i długość życia człowieka, 
migracje ludzi, a także badania naukowe (Domański 1993, s. 20). W związku z tym komparatyści skupiają się na porównaniu efektywności edukacji publicznej, działalności prywatnych placówek edukacyjnych, efektywności wykorzystania zainwestowanych środków w edukację oraz na zarządzaniu oświatą w różnych państwach świata (Lokszyna 2014, s. 8).

\section{Etapy rozwoju pedagogiki porównawczej}

Pedagogika porównawcza przeszła kilka faz rozwoju, w trakcie których zmieniały się jej funkcje, cele, podejścia do niej i metody. W tej części opracowania chciałabym przedstawić periodyzacje rozwoju pedagogiki porównawczej autorstwa George'a Beredeya; Harolda Noaha i Maxa Ecksteina i Aliny Sbrujewej. Z uwagi na ograniczoną objętość artykułu podam jedynie nazwy etapów, ramy czasowe, motywy oraz idee kluczowe periodyzacji. Szczególna uwaga zostanie poświęcona periodyzacji rozwoju pedagogiki porównawczej António Nóvoa i Tili Yariv-Mashal, ponieważ obejmuje ona wiek XXI. Pierwsza periodyzacja, która została zaprezentowana przez George’a Beredaya w pracy Metoda porównawcza w edukacji (Comparative method in education, 1964) składa się z trzech etapów rozwoju. W tabeli 1. zostały przedstawione nazwy etapów i ramy czasowe rozwoju pedagogiki porównawczej.

Tabela 1. Periodyzacja rozwoju pedagogiki porównawczej wg G. Beredaya (1964, s. 241-250)

\begin{tabular}{|l|l|l|}
\hline \multicolumn{1}{|c|}{ Etapy } & \multicolumn{1}{c|}{ Nazwa etapu } & \multicolumn{1}{c|}{ Ramy czasowe } \\
\hline Pierwszy & Zapożyczenia & XIX wiek \\
\hline Drugi & Prognozowanie & Pierwsza połowa XX wieku \\
\hline Trzeci & Analiza & Lata 50-70 XX wieku \\
\hline
\end{tabular}

Następna periodyzacja rozwoju pedagogiki porównawczej była przedstawiona przez amerykańskich naukowców Harolda J. Noaha i Maxa A. Ecksteina. W rozwoju pedagogiki porównawczej naukowcy ci wyróżnili pięć etapów, akcentując w nich motywy, którymi kierowali się badacze. Periodyzacja ta została opracowana w 1969 roku. 
Tabela 2. Periodyzacja rozwoju pedagogiki porównawczej wg H.J. Noaha i M.A. Ecksteina (1969, s. 64-67)

\begin{tabular}{|l|l|l|}
\hline \multicolumn{1}{|c|}{ Etapy } & \multicolumn{1}{|c|}{ Ramy czasowe } & \multicolumn{1}{c|}{ Motyw } \\
\hline Pierwszy & XIX wiek & Ciekawość \\
\hline Drugi & $\begin{array}{l}\text { Pierwsza połowa XIX wieku - } \\
\text { lata 8o. XIX wieku }\end{array}$ & Doświadczenia zagraniczne \\
\hline Trzeci & Koniec XIX wieku & $\begin{array}{l}\text { Ustalenie światowej harmonii i ulepszenie } \\
\text { życia społecznego }\end{array}$ \\
\hline Czwarty & Pierwsza połowa XX wieku & $\begin{array}{l}\text { Poszukiwanie czynników kształtujących } \\
\text { narodowe systemy edukacyjne }\end{array}$ \\
\hline Piąty & Druga połowa XX wieku & $\begin{array}{l}\text { Wzajemne oddziaływanie czynników spo- } \\
\text { łecznych i edukacyjnych }\end{array}$ \\
\hline
\end{tabular}

Kolejną periodyzację rozwoju pedagogiki porównawczej przedstawiła ukraińska badaczka Alina Sbrujewa. Etapy rozwoju pedagogiki porównawczej zostały przez nią opracowane na podstawie badań amerykańskich Williama Brickmana, George’a Beredaya, Davida N. Wilsona, Wolfganga Mittera i rosyjskich komparatystów Borisa Wulfsona i Zoji Małkowej.

Tabela 3. Periodyzacja rozwoju pedagogiki porównawczej według A. Sbrujewej (1999, s. $30-42)$

\begin{tabular}{|c|c|c|}
\hline Etapy & Nazwa etapu & Ramy czasowe \\
\hline Pierwszy & Klasyczny (wg W. Brickmana)/ prehistoryczny & $\begin{array}{l}\text { Od czasów najdawniejszych do } \\
\text { początku XIX wieku }\end{array}$ \\
\hline Drugi & $\begin{array}{l}\text { Zapożyczeń (wg G. Beredaya)/ } \\
\text { opisowy (wg D. Wilsona)/ } \\
\text { przygotowawczy (wg W. Mittera) }\end{array}$ & XIX wiek \\
\hline Trzeci & Początek badań w pedagogice porównawczej & Pierwsza połowa XX wieku \\
\hline Czwarty & $\begin{array}{l}\text { Rozwój metodologii pedagogiki porównawczej } \\
\text { (wg D. Wilsona }\end{array}$ & Lata 50-80. XX wieku \\
\hline Piąty & $\begin{array}{l}\text { Period globalizacji, regionalizacji i internacjo- } \\
\text { nalizacji światowej przestrzeni edukacyjnej }\end{array}$ & $\begin{array}{l}\text { Lata } 80 . \text { XX wieku i początek XXI } \\
\text { wieku }\end{array}$ \\
\hline
\end{tabular}

Alina Sbrujewa ujęła opracowania zagranicznych badaczy w kontekście ukraińskim i na ich podstawie przedstawiła etapy rozwoju pedagogiki porównawczej na Ukrainie w skali globalnej.

Periodyzacja opracowana przez António Nóvoa i Tali Yariv-Mashal obejmuje cztery okresy. 
Tabela 4. Periodyzacja rozwoju pedagogiki porównawczej wg A. Nóvoa, T. Yariv-Mashal (2003b, s. 423-426)

\begin{tabular}{|l|l|l|}
\hline \multicolumn{1}{|c|}{ Etapy } & \multicolumn{1}{c|}{ Kluczowa idea } & \multicolumn{1}{c|}{ Ramy czasowe } \\
\hline Pierwszy & Wiedza o innych & $\begin{array}{l}\text { 1880 i koniec } \\
\text { lat 20. XX wieku }\end{array}$ \\
\hline Drugi & Zrozumienie innych & Lata 20-50. XX wieku \\
\hline Trzeci & Konstruowanie innych & Lata 60. XX wieku -20oo rok \\
\hline Czwarty & Ocenianie innych & XXI wiek \\
\hline
\end{tabular}

Lata 8o. XIX wieku charakteryzują się badaniami dotyczącymi przeprowadzonych w różnych krajach reform edukacji. Celem tych badań była konsolidacja narodowych systemów edukacyjnych. Zasada, według której można „uczyć się wiedzy o innych”, dała początek eksplorowaniu przez badaczy innych państw w celu zyskania nowych doświadczeń.

$\mathrm{Na}$ tej podstawie zostały opracowane materiały na temat warunków i reguł życia w poszczególnych państwach. Reorganizacja światowej przestrzeni była wyzwaniem dla zamkniętych systemów edukacji. Transformacja polityki oświatowej w różnych państwach miała decydujące znaczenie dla rozwoju pedagogiki porównawczej (Nóvoa 2001, s. 43). W latach 20. XX wieku badacze skierowali swój wysiłek na współpracę międzynarodową. Powstanie takich instytucji jak Instytut Międzynarodowy (Institute of International Education, New York, 1923); Biuro Edukacji Międzynarodowej (International Bureau of Education, Genewa, 1925) świadczyło o dalszym rozwoju nauki. Pojawiająca się wkrótce seria międzynarodowych raportów, rozpowszechnienie międzynarodowych danych odegrało znaczącą rolę w zrozumieniu doświadczeń innych krajów.

Lata 6o. XX wieku charakteryzują się zainteresowaniem edukacją ze strony polityków i naukowców. Z jednej strony odbyły się istotne zmiany w treści systemów edukacji, $w$ tym $w$ polityce inwestycyjnej dotyczącej edukacji, a $z$ drugiej strony próba odnowienia badań porównawczych z wykorzystaniem teorii i metodologii nauk społecznych.

Początek XXI wieku jest okresem, w którym w większym stopniu zaczęto wykorzystywać technologię informacyjną i komunikacyjną oraz współpracować na skalę międzynarodową. Nie chodzi tu o standaryzację czy homogenizację systemów edukacyjnych, lecz przede wszystkim o przyjęcie wspólnych metod badawczych i narzędzi. „Ocenianie innych” jest porównywaniem siebie do innych. To właśnie ocenianie innych i spojrzenie na innych „pozwala zachować własne poglądy, odkrywając dla siebie niezauważalne jak dotąd możliwości. To nie przypadek, że najważniejsze wydarzenia w pedagogice porównawczej zbiegają się w czasie z tymi «gorącymi okresami» w historii" (Nóvoa, Yariv-Mashala 2003a, s. 423). 


\section{Współczesne spojrzenie na pedagogikę porównawczą}

Większość prac z pedagogiki porównawczej, aż do drugiej połowy XX wieku, była poświęcona wyłącznie badaniom nad krajowymi systemami edukacji. Na początku XXI wieku nastąpiły istotne zmiany w dziedzinie pedagogiki. Jako dyscyplina naukowa pedagogika porównawcza sytuuje się na styku takich dziedzin naukowych jak: polityka oświatowa, socjologia, ekonomia, socjologia, prawo, pedagogika społeczna i psychologia. Pedagogika porównawcza ma charakter interdyscyplinarny. Irina Tagunowa (2011, s. 137) przedstawiła badanie przeprowadzone przez grupę komparatystów w 2010 roku wśród naukowców zajmujących się badaniami porównawczo-pedagogicznymi. Stwierdzili oni, że na ich pracę duży wpływ mają nauki społeczne, $\mathrm{z}$ których czerpią metodologię i teorię dla swoich badań. Ponad 80 proc. zgłosiło identyfikację z socjologią, ok. 70 proc. - z naukami politycznymi, prawie 60 proc. powiązało swoje badania $z$ historią, a połowa wszystkich badaczy zgłosiła związek z ekonomią. Z czasem komparatyści stracili zainteresowanie psychologią, która jest bliska pedagogice. Jak podkreślił Goran Therborna, „W swoim małym świecie dyscypliny naukowe przypominają państwa narodowe, ponieważ ich wymiary, granice i cechy charakterystyczne są uwarunkowane historycznie. Państwa dążą do tworzenia własnych historycznych podstaw i mitów; roszczą sobie prawo do suwerenności, czasem spornej; angażują się w walkę o granice. Tak samo jak walczy każda nauka za swoje miejsce wśród innych dyscyplin” (2000, s. 275).

Najczęściej badacze w swoich pracach wracali się do teorii politycznej, socjologicznej, filozoficznej i ekonomicznej: 11,1 proc. respondentów wskazało teorię krytyczną; 8,1 proc. - teorię etnograficzną; 7,3 proc. - teorię konstruktywistyczną; 7 proc. - teorię modernizacji; 7 proc. - teorię zależności; 7 proc. - teorii filozoficznej marksizmu i neomarksizmu;6,8 proc. - teorię systemu światowego; 6,2 proc. - teorię kapitału ludzkiego; 6,2 proc. - teorię polityczną (pluralizm) i 5,4 proc. - teorię funkcjonalizmu strukturalnego. Teorie psychologiczne rzadko były stosowane przez badaczy (Tagunowa 2011, s. 137). Taka sytuacja doprowadziła do wniosku, że pedagogika porównawcza zrezygnowała z przedmiotu własnych badań oraz swojej metodologii instynktownie, poszukując innej podstawy badawczej, na której mogłaby budować swoje badania. W XXI wieku w prezentowaniu nowych teorii wiodącą rolę zajmują socjologia, ekonomia i nauki polityczne. Właśnie do nich dołączyła się pedagogika porównawcza.

H.J. Noah już w 1973 roku stwierdził, że przy współczesnym podejściu do analizy porównawczej należy odejść od badań krajowych na rzecz takich, które łączą zmienne z wielu krajów. Z jego punktu widzenia, aby badania można było nazwać porównawczymi, powinny być spełnione dwa powiązane ze sobą warunki: dane o problemie powinny być zbierane na poziomie uogólnionym, a analiza powinna być prowadzona na poziomie systemowym (1973, s. 109).

We współczesnym zglobalizowanym świecie istnieje zapotrzebowanie na porównawcze informacje edukacyjne, które pomogą narodowym systemom edukacyjnym 
odnaleźć się w szybko zmieniającej się przestrzeni edukacyjnej. Na jej gruncie toczy się „,niezadeklarowana wojna” o przetrwanie, zatem następuje „redystrybucja wpływów" i pojawiają się pewne nisze w świadczeniu usług edukacyjnych. Wszystkie możliwości promowania edukacji narodowej jako kategorii gospodarczej związane są przede wszystkim z poziomem dostosowania edukacji do międzynarodowego poziomu jakości. Globalizacja to także wysoki poziom komunikacji rozumianej jako główny proces powstawania, rozwoju i przekształcania rzeczywistości społecznej, w tym edukacji. Cała ta sytuacja społeczna w edukacji doprowadziła do pojawienia się nowych metod badawczych, a przedmiotem zainteresowania badaczy stała się globalizacja przestrzeni edukacyjnej. W tych warunkach komparatyzm zaczyna uważać mass media, internet i inne technologie cyfrowe za główną instytucję społeczną, która przekształca świat edukacji. Pojęcie komunikacji staje się decydującym czynnikiem zrozumienia edukacji w wymiarze globalnym. Jest ona przedstawiona zarówno jako przyczyna, jak i wynik interakcji w sieci.

Do zmian w badaniach porównawczo-pedagogicznych przyczynił się internet. Edukacja stała się systemem otwartym na cały świat, w którym narodowe paradygmaty, wartości, treści i formy wzajemnie na siebie oddziałują. W związku z tym głównym zadaniem badań porównawczych $w$ edukacji jest po pierwsze rozwiązanie sprzeczności pomiędzy narodową specyfiką interakcji komunikacyjnej w edukacji a międzynarodową interakcją komunikacyjną, a po drugie identyfikacja i rozwój technologii wdrażania doświadczenia pedagogicznego, jako części przestrzeni edukacyjnej. Zatem analiza systemów edukacyjnych powinna być prowadzona w kontekście sieci, co oznacza rozpatrywanie lokalnych systemów edukacyjnych jako wewnętrznie powiązanych ze sobą oraz wzajemnie połączonych technologią informacyjną. Jednocześnie sieć zaczyna determinować rozwój edukacji we wszystkich krajach. W tej sytuacji logiczne wydaje się badanie rozwoju sieci, a także transformacji każdego krajowego systemu edukacji.W tym modelu badawczym porównania można dokonać jedynie przy użyciu metod interpretacyjnych i poprzez poznanie obiektu badań w rozwoju, czyli w trzech perspektywach czasowych: przeszłości, teraźniejszości, przyszłości. Model ten zakłada przede wszystkim predykcyjną wizję problemu, określenie perspektywy rozwoju samej sieci. Identyfikacja trendów rozwojowych edukacji w ramach takiego modelu opiera się na zweryfikowanych matematycznie wynikach badań dużych projektów międzynarodowych, w szczególności TIMSS, PISA, PIRLS i innych. Badacz może zaproponować różne kierunki przekształceń własnego systemu edukacji, interpretując wyniki badań prowadzonych w skali globalnej.

„Metoda sieci” jest jakościową metodą badawczą. Polega ona na zbieraniu informacji w sposób swobodny, jednocześnie przy skoncentrowaniu się na zrozumieniu, wyjaśnieniu i interpretacji danych już opisanych lub przedstawionych w doświadczeniu, które są źródłem hipotez i koncepcji. Celem tej metody jest gromadzenie informacji z różnych źródeł poprzez wyjaśnienie i interpretację danych. Mogą to być: wyniki obserwacji i oceny ekspertów; dokumenty, monografie, artykuły 
oraz informacje ze stron internetowych. Ponadto ta metoda jakościowa obejmuje analizę krytyczną wszystkich rodzajów materiałów, syntezę materiału naukowego i uogólnienie. Badacz stosujący metodę jakościową powinien mieć bogate doświadczenie naukowe, posiadać wiedzę teoretyczną w zakresie interpretacji analizowanych faktów, a także mieć stały kontakt z zagranicznymi kolegami. Głównym elementem metody „sieci” są dane pozyskiwane z różnych źródeł. Innym są różne procedury analityczne lub interpretacyjne, stosowane w celu uzyskania danych i konceptualizacji badań.

Opisywana metoda ma za zadanie spełniać następujące kryteria: powinna opierać się na dużej liczbie informacji, a sposób prezentacji materiału powinien mieć charakter wyjaśniający i prognostyczny, zaś wyniki powinny być przedstawione jako hipotetyczne. Oprócz tego „metoda sieci” obejmuje: a) bezpośrednią obserwację rzeczywistości, jeśli tylko jest to możliwe; b) uznanie badanego zjawiska (faktu, systemu, procesu, teorii) za stale ewoluujące; c) identyfikację zmian w paradygmatach edukacyjnych; d) skupienie uwagi na zmienności i złożoności współczesnych systemów edukacyjnych, teorii i koncepcji; e) badanie wszelkich związków w edukacji i nauce; f) prognozowanie pojawienia się pewnego zjawiska w edukacji i nauce; g) uzasadnienie perspektyw rozwoju edukacji. Stosując tę metodę, badacz powinien zwracać uwagę na: 1) definiowanie warunków będących przyczyną powstania pewnego zjawiska i jego rozwoju; 2) kontekst, w którym to zjawisko zostało realizowane; 3 ) interakcje, poprzez które to zjawisko się przejawia; 4) transformacje badanego zjawiska.

W opinii A. Nóvoa, T. Yariv-Mashal (2003b, s. 64), „Co kilka lat dochodzi do reorganizacji świata, co z kolei odzwierciedla się w poszukiwaniu nowej równowagi. Świat państw narodowych, który znamy od XX wieku ustępuje miejsca złożonym konstrukcjom politycznym, w których stosunki międzynarodowe są definiowane poprzez sieci komunikacyjne i języki, które wnoszą nowe reguły w proces umiędzynarodowienia".

Proces globalizacji jest ścisłe związany z edukacją. W przestrzeni edukacyjnej ciągle toczą się dyskusje na temat krajowego systemu edukacji, który winien odpowiadać międzynarodowemu poziomowi jakości kształcenia. Globalizacja w edukacji umożliwia systemom edukacyjnym poprawienie jakości poprzez nabywanie doświadczeń zagranicznych. Środki masowego przekazu, internet i inne technologie cyfrowe stają się podstawą działań społecznych, a koncepcja komunikowania istotnym czynnikiem w zakresie zrozumienia edukacji w wymiarze globalnym.

\section{Zakończenie}

Do dziś badacze nie mogą odpowiedzieć na pytanie, jakie 50 lat temu postawił francuski komparatysta Aleksander Vexliard: „Czy pedagogikę porównawczą należy traktować jako samodzielną dyscyplinę, czy jako subdyscyplinę pedagogiki ogólnej, czy też historii pedagogiki? Czy może powinna ona być związana z innymi naukami 
takimi jak: socjologia, psychologia, politologia, filozofia edukacji?” (Vexliard 1967, s. 5). Rosyjski komparatysta Boris Wolfson (2003, s. 47) zauważa, że „do tej pory wśród komparatystów nie ma zgody w określeniu przedmiotu badań pedagogiki porównawczej oraz jej granic z innymi naukami. Samo określenie przedmiotu i celów badań, metod, narzędzi i technik nie wystarczy, aby przedstawić prawidłowe rozumienie metodologii tej subdyscypliny".

Pedagogika porównawcza ma charakter interdyscyplinarny i dlatego potrzebuje danych z innych nauk. Stanowi ona instrument służący do analizy systemów oświatowych. Zadaniem pedagogiki porównawczej jest zebranie i sklasyfikowanie niezbędnych informacji o systemach edukacji, instytucjach, programach, metodach nauczania, nauczycielach i uczniach, jak również o jawnych lub ukrytych wpływach kulturowych i filozoficznych. Zatem próbuje ona wyjaśnić, dlaczego zjawiska funkcjonują w taki, a nie inny sposób, analizuje zebrane dane o systemach edukacji, na które mają wpływ zjawiska społeczne, ekonomiczne, technologiczne, religijne i filozoficzne, a także uprzedzenia rasowe i narodowe.

Globalizacja oraz reformy ukierunkowane na podniesienie efektywności kształcenia w latach 80. XX wieku spowodowały zmiany w edukacji. W dążeniach do optymalizacji swej pracy naukowcy coraz częściej korzystają z osiągnięć międzynarodowych analiz porównawczych w odniesieniu do badań edukacyjnych, odzwierciedlają one bowiem zmiany zachodzące we współczesnym świecie. Poza tym czynniki globalizacyjne wywołują szereg zjawisk, dlatego też wymagają one prowadzenia badań $w$ celu zidentyfikowania wspólnych tendencji rozwoju, gdyż globalizacja, jak zauważa Mark Brey, zmusza wręcz badaczy do stworzenia „nowej kartografii geopolitycznej, która formuje nowe przykłady naśladownictwa, dominacji i subordynacji w polityce i praktyce oświatowej" (2003, s. 219).

Reasumując, dzięki procesom globalizacji metodologia pedagogiki porównawczej na obecnym etapie wzbogaca się o nowe metody tak potrzebne w celu sprostania wyzwaniom, przed którymi stoi współczesny człowiek, w postaci zmniejszenia nierówności zarówno wewnątrz państw, jak i pomiędzy nimi, tworzenia warunków sprzyjających rozwojowi społecznemu i przeciwdziałania tym nierównościom (Zajda 2008).

\section{Bibliografia}

Bray M. (2003). Comparative Education in the Era of Globaliiation: Evolution mission and rules". Policy Futures in Education", nr 1 (2), s. 209-224.

Bereday G.Z. F. (1964). Comparative Method in Education. New York: Holt, Rinehart and Winston.

De Landsheere G. (1972). Dictionnaire de l'Évaluation et de la Recherche en éducation. Paris: Presses Universitaires de France.

Domański S.R. (1993). Kapitał ludzkii wzrost gospodarczy. Warszawa: Państwowe Wydawnictwo Naukowe. 
Dudko S. (2018). Osobennosci metodologii sowremennych srawnitelno-pedagogiczeskich issledowanij $w$ Rossii I Francii. „Oteczestwennaja I zarubeżnaja pedagogika", nr 1 (46), s. 6o-71.

Groux D., Perez S. (2002). Dictionnaire d'éducation compare. Paris: L'Harmattan.

Groux D. (1997). L'éducation comparée: approaches actuelles et perspectives de développement. „Revue française de pédagogie”, s. 111-139.

Halls W.D. (1990). Tendances et problèmes de l'éducation comparée. L'Éducation comparée: questions et tendances contemporaines. Paris: UNESCO.

Hans N. (1948). Comparative Education: A study of educational factors and traditions. London: Routledge \& Kegan Paul.

Holmes B. (1965). Problems in Education: A Comparative Approach. London: Routledge \& Kegan Paul.

Jullien de Paris M.A. (1817). Esquisses et vues préliminaires d'un ouvrage sur l'éducationcomparée. Paris: Société Établie à Paris pour l'Amélioration de l'Enseignement Elémentaire. Reprinted 1962. Genève: Bureau International d'Éducation.

Kandel I. (1955). The New Era in Education. Cambridge. Mass: Houghton and Mifflin Inc.

Lé Thành Khôl (1981). L'Éducation comparée. Paris: Armand Colin.

Lokszyna O. (2014). Profesionalizacja poriwnialnoji pedagogiky w Ukrajini: zdobutky i wyklyky u wymiri pedagogicznoji komparatywistyky u zarubiżżi. „Poriwnialnopedagogiczni studiji”, nr 6 20), s. 5-12.

Mattheou D. (2006). Promouvoir la compréhension mutuelle en matière d'éducation en Europe. Les visites d'étude et la contribution de l'éducation comparée. „Formation professionnelle”, nr 34, s. 6-16.

Nóvoa A. (2001). États des lieux de l'Éducation comparée, paradigmes, avancées et impasses. W: Sirota R. (red.). Autour du comparatisme en Éducation. Paris: PUF, s. 41-68.

Nóvoa A., Yariv-Mashal, T. (2003a). Comparative Research in Education: a mode of governance or a historical journey? "Comparative Education”, nr 39 (4), s. $423-438$.

Nóvoa A., Yariv-Mashal T. (2003b). Le Comparatisme en Éducation: mode de gouvernance ou enquête historique? W: Laderrière P., Vaniscotte F. (red.). L'Éducation comparée: un outil pour l'Europe. Paris: L'Harmattan, s. 57-82.

Noah H.J., Eckstein M.A. (1969). Toward a Science of Comparative Education. New York: Macmillan.

Noah H.J. (1973). Defining Comparative Education. Conceptions. W: Relevant Methods in Comparative Education. Reginald E. (red.). Hamburg: UNESCO Institute for Education.

Porcher L. (2008). L'éducation comparée: pour aujourd'hui et pour demain. Paris: L'Harmattan. 
Sadler M. (1900). How far can we learn anything of practical value from the study of foreign systems of education? W: Higginson J.H. (red.). Selections from Michael Sadler. Liverpool: Dejall\&Meyorre.

Sbrujewa A. (1999). Poriwnjalna pedagogika. Sumy: SDPU.

Tagunowa I. (2011). Pedagogiczeskaja komparatiwistika: wczera, segodnia, zawtra. „Obrazowanie i pedagogiczeskaja nauka za rubeżom”, 1, s. 132-146.

Therborn G. (2000). Their Knowledge: The Times and Place of the World and Other Systems. „Journal of World System Research”, nr 6 (2), s. 266-284.

Thomas R.M. (1990). International Comparative Education: Issues and Prospects. New York: Pergamon Press.

Van Daele H. (1993). L'éducation comparée. Paris: Presses Universitaires de France. Vexliard A. (1967). La pédagogie comparée. Méthodes et problèmes. Paris: Presses Universitaires de France.

Wulfson B., Małkowa Z. (1996). Srawnitelnaja pedagogika; uczebnojeposobije. Woroneż: MODEK.

Wulfson B. (2003). Srawnitelnajapedagogika: istorijaisowremennyje problemy. Moskwa: Izdatelstwo URAO.

Yamada S. (2015). The Constituent Elements of Comparative Education in Japan: A Comparison with North America. „Comparative Education Review”, nr 59 (2), s. 234-260.

Zajda J. (2008). Globalization, Comparative Education and Policy Research: Equity and Access Issues. W: Zajda J., Gibbs D. (red.).Comparative and Global Pedagogies. Dordrecht: Springer Science + Business Media B.V.

\title{
COMPARATIVE PEDAGOGY IN THE SYSTEM OF CONTEMPORARY SCIENTIFIC KNOWLEDGE
}

\begin{abstract}
The methodology of comparative and pedagogical research is currently undergoing certain changes, the scope of which is interesting to researchers from other fields. The starting point of this article is the theoretical and methodological basis of comparative pedagogy. The first part of the study is a specific introduction to the theoretical and methodological bases of comparative pedagogy. The author presents the aims and definitions of comparative pedagogy, as well as describes the importance of comparative pedagogy for the development of the education system. The second part is devoted to a historical view of the evolution of comparative pedagogy. The next part of the article presents the stages of development of comparative pedagogy. The last subsection discusses the processes of globalization in education.
\end{abstract}

Keywords: comparative pedagogy, comparative research, methodology, network method. 